\title{
STUDY ON CONCEPTUAL DESIGNS OF SUPERCONDUCTING COIL FOR ENERGY STORAGE IN SMES
}

\author{
(D)Md. Abdullah Al Zaman ${ }^{a *}$, (D)M.R. Islam ${ }^{b}$, (D)H.M.A.R. Maruf \\ ${ }^{a}$ Department of Textile Engineering, Northern University Bangladesh, Dhaka, Bangladesh \\ ${ }^{b}$ Department of Physics, University of Chittagong, Chittagong 4331, Bangladesh \\ ${ }^{c}$ Department of Physics, Chittagong University of Engineering and Technology, Chittagong- 4349, Bangladesh \\ *Corresponding Author: proyashzaman@gmail.com \\ Received October 12, 2019; revised November 22, 2019; accepted January 21, 2020
}

Superconducting Magnetic Energy Storage (SMES) is an exceedingly promising energy storage device for its cycle efficiency and fast response. Though the ubiquitous utilization of SMES device is restricted because of the immense cost of cryogenic refrigeration system to sustain the superconducting state but with the continuous evolution of high Tc superconductors, SMES is turning into a major contender to the existing energy storage devices in the future. Among its several parts, the superconducting coil is considered to be the most crucial segment of this technology and the inductance generated in the coil determines the quantity of stored energy. In this paper, the possible geometrical configurations of SMES coil have been demonstrated. High Tc superconducting tapes are usually employed to form these configurations worldwide. BSCCO (Bismuth strontium calcium copper oxide)-2223 tape superconductor has been considered for studying the conceptual designs of superconducting coil of SMES. Before estimating the results, the value of critical current at different magnetic field densities and temperatures have been addressed through the study of superconducting tape characterization. Numerical results and the relationship among the several parameters for both the solenoid and toroid configurations in different specifications have been presented. Based on the results, the size ratio in solenoid and the mean toroid diameter in toroid arrangement is found to play the vigorous roles in the generation of inductance and hence the energy storage. The results also match the propensity of other studies. Suggestions for maximum energy gain from a specific solenoid configuration have been provided. Future research scopes with alternative superconducting tapes and limitations of this study have been briefly conferred.

KEYWORDS: SMES, inductance, energy storage device, solenoid, toroid.

Superconducting magnetic energy storage (SMES) is one of the benedictions of superconductivity. SMES stores energy in the form of magnetic field produced by the flow of direct current in a superconducting coil which has been cryogenically cooled to a temperature below its superconducting critical temperature (Tc). The stored energy can be released back to the network by discharging the coil [1]. Discovery of high-Tc materials as well as the development of other equipment is making SMES a better option in energy storage facilities [2]. SMES is considered as one of the most efficient energy storage systems and its lifetime is also relatively higher than the other storage systems [2]. SMES can be used in several ways like FACTS (Flexible AC Transmission System), UPS (Uninterruptible Power Supplies), System stabilizer and so on [3]. The essential parts of a SMES system consist of superconducting coil with the magnet (SCM), power conditioning system (PCS), cryogenic system (CS) and control unit (CU) [3]. Of them, the superconducting magnet coil or inductor is the most important part for technical as well as electrical perspective. The SCM is considered as the heart of the SMES technology. It is well known that the storage energy depends on fixed operating current $\mathrm{I}$ (of course below the critical current, $\mathrm{I}_{\mathrm{c}}$ ) and the inductance of the magnet coil. The possible way of increasing energy storage is to increase the inductance of the respective coil. Therefore, it is necessary to study the magnet coil which can be done by observing its characteristics. Since the beginning, there have been many experimental and theoretical studies led on this topic. There are three types of coils that may be considered; Solenoid, Multiple solenoid and toroid coil. Here, we will present the study on conceptual designs and theoretical considerations of superconducting magnet coils (solenoid and toroid) of SMES system for energy storage purpose. Before going to the key section, pertinent formulas utilized in this study have been introduced for understanding the study goal.

\section{INDUCTANCE, ENERGY AND VOLUME OF A SMES COIL}

When a DC current is passed in a normal conductor the energy would be dissipated due to the resistance of the wire. But when the flow of DC current in a wire made of the material that possesses superconducting behavior, a magnetic field is generated due to the flow under proper condition. This means that the energy will be stored in the form of a magnetic field in a persistent mode and will remain the same until utilized. A very steady DC current will also exist in a closed circuit due to the zero resistance environment of a superconductor. This principle works on a superconducting coil storing electrical energy in the form of magnetic field and the stored energy will be inductive. It can be written in the form $[4,5]$,

$$
E=\frac{1}{2} L I^{2}
$$

where, $L=$ Inductance of the coil, $I=$ current that flows through the coil. 
While designing a SMES system the calculation of inductance of the coil is very important to understand how much energy can be gained from this and how to accumulate or connect the other components including the protection. Typically there are two kinds of SMES magnet topologies:

1. Solenoid and

2. Toroid.

\section{SOLENOID CONFIGURATION}

Solenoid configuration is frequently used due to its simple winding process, high stray field and non -uniform stress. Fig.1(a) and 1(b) are showing the construction of the superconducting magnet in the solenoid configuration in a SMES system.

The inductance of a solenoid coil can be written in the form [5],

$$
L=\pi \mu_{0}\left(\frac{N^{2} D_{i}}{16 \beta}\right) \frac{(\alpha+1)^{2}}{1+0.9\left(\frac{\alpha+1}{4 \beta}\right)+0.64\left(\frac{\alpha-1}{\alpha+1}\right)+0.84\left(\frac{\alpha-1}{2 \beta}\right)},
$$

where $N$ is the total number of turns of the solenoid, $D_{0}$ is the outer radius and $D_{i}$ is the inner radius of the solenoid coil. $\alpha$ and $\beta$ are the size ratios which are determined by the following formulas,

$$
\alpha=\frac{D_{0}}{D_{i}} \quad \text { and } \quad \beta=\frac{H}{D_{i}}
$$

where $H$ is the total height of the coil and

$$
H=W_{p} n_{p}
$$

where: $n_{p}=$ the number of pancake and $W_{p}=$ width of the superconducting tape.

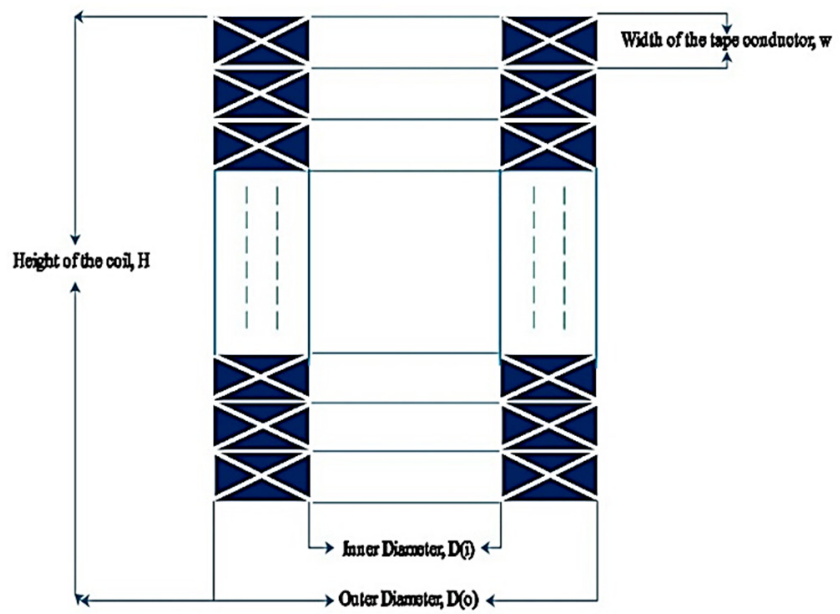

Fig. 1(a) SMES Coil in solenoid configuration

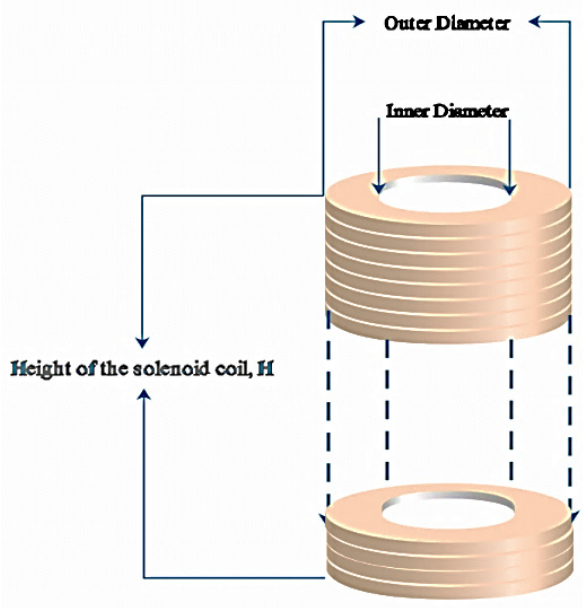

Fig. 1(b). Three dimensional representation of SMES Coil in solenoid configuration

The total number of turns of the coil $N$ of the solenoid is determined by the relation

$$
N=n \times n_{p}
$$

Here, $\mathrm{n}$ is the number of turns in each pancake and is written as

$$
n=\frac{\text { outer Diameter }\left(D_{0}\right) \text {-inner diameter }\left(D_{i}\right)}{2 t}
$$

where $t$ is the thickness of the tape conductor.

Using Eq. (1) for inductance $L$ and replacing $I$ by $I_{c}$, the energy stored in a solenoid coil for a critical current $I_{c}$

$$
\mathrm{E}=\frac{\mathrm{I}_{\mathrm{C}}^{2}}{2}\left\{\pi \mu_{0}\left(\frac{\mathrm{N}^{2} \mathrm{D}_{\mathrm{i}}}{16 \beta}\right) \frac{(\alpha+1)^{2}}{1+0.9\left(\frac{\alpha+1}{4 \beta}\right)+0.64\left(\frac{\alpha-1}{\alpha+1}\right)+0.84\left(\frac{\alpha-1}{2 \beta}\right)}\right\}
$$

Here, $I_{c}(>I)$ is the maximum current sustain in a superconducting coil, determined by the relation

$$
\mathrm{I}_{\mathrm{c}}=\mathrm{J}_{\mathrm{c}} \mathrm{A}_{\mathrm{sc}},
$$

where $\mathrm{J}_{\mathrm{c}}=$ critical current density of the superconducting tape in $\left(\mathrm{A} / \mathrm{m}^{2}\right), \mathrm{A}_{\mathrm{sc}}=$ Area through which current flows And the area $\left(\right.$ in $\mathrm{m}^{2}$ ) can be written as 


$$
\mathrm{A}_{\mathrm{sc}}=W_{p} t
$$

The total volume of the SMES coil in solenoid arrangement can be written as (Figure 2)

$$
V_{1}=\pi r_{1}^{2} H
$$

And the volume of the inner empty space

$$
V_{2}=\pi r_{2}^{2} H
$$
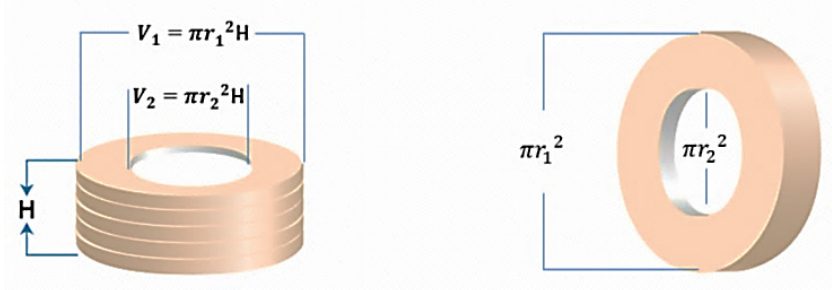

Fig. 2. Schematic for volume analysis of SMES coil

where $r_{1}$ is the outer radius and $r_{2}$ is the inner radius which can be calculated from

$$
r_{1}=\frac{D_{o}}{2} \text { and } r_{2}=\frac{D_{i}}{2}
$$

So the volume of the superconducting material is

$$
V_{S C}=V_{1}-V_{2}=\pi r_{1}^{2} H-\pi r_{2}^{2} H
$$

\section{TOROID CONFIGURATION}

In the toroid arrangement, the winding process is relatively complex but there are no limits to the stray field and the stress can be optimized more efficiently than the solenoid arrangement of the superconducting coil for the SMES system [6]. In Fig. 3(a) and 3(b) are showing the construction of the toroid configuration.

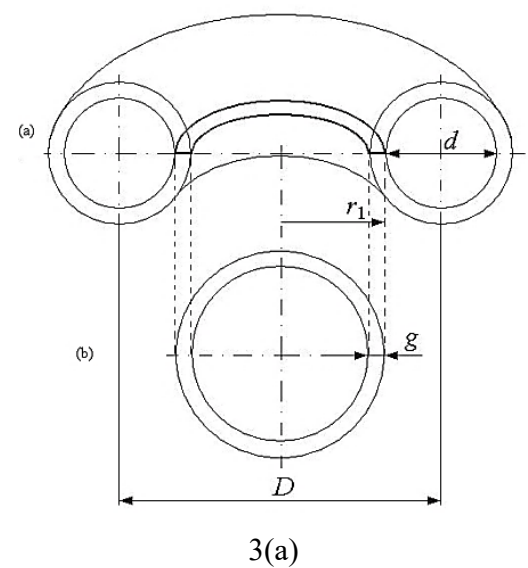

Fig. 3(a). SMES Coil[7] in Toroid configuration

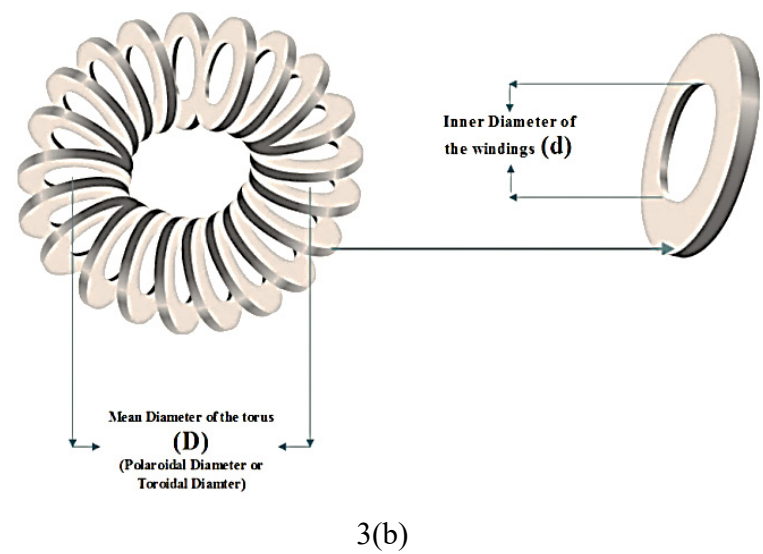

Fig. 3(b): Three dimensional representation of SMES Coil in Toroid configuration

In the Fig. 3(a) and 3(b) $D$ is the mean diameter of torus, $d$ is the inner diameter of winding and $g$ is the thickness. For a thin winding torus, the exact analytical expression of inductance is written as $[4,7]$.

$$
L=\frac{\mu_{0}}{2}\left[D-\sqrt{D^{2}-d^{2}}\right],
$$

where $\mu_{0}=$ permeability in the vacuum.

Using equation (14), the energy stored in a toroid coil now can be written as

$$
E=\frac{1}{2} L I_{c}^{2}=\frac{\mu_{0} I_{c}^{2}}{4}\left[D-\sqrt{D^{2}-d^{2}}\right]
$$

The total section or area of superconductor corresponding to the inner radius shown in Figure 2(b) is [7]

$$
\mathrm{A}_{\mathrm{sc}}=\pi g(D-d-g)
$$


Using equation (8) and (16), equation (15) can be written as,

$$
E=\frac{\mu_{0} J_{c}^{2}}{4} \pi^{2} g^{2}(D-d-g)^{2}\left[D-\sqrt{D^{2}-d^{2}}\right]
$$

The volume of the superconducting material [7]

$$
V_{S C}=\pi^{2} g(D-d-g)(d+g)
$$

Let us define,

$$
\alpha=\frac{d}{D} \text { and } \beta=\frac{g}{D}
$$

The energy and volume equations in terms of size ratio can be expressed as

$$
\begin{gathered}
E=\frac{\mu_{0} J_{C}^{2}}{4} \pi^{2} \beta^{2} D^{5}(1-\alpha-\beta)^{2}\left[1-\sqrt{1-\alpha^{2}}\right] \\
V_{S C}=\pi^{2} D^{2}(1-\alpha-\beta)(\alpha+\beta)
\end{gathered}
$$

\section{HTS TAPE CHARACTERIZATION}

Superconducting tapes or more specifically high temperature superconductor (HTS) tapes plays the major role in determining the quantity of inductance as well as the energy stored in the SMES system. But before utilization we have to understand the characteristics of the tapes that provide the proper idea about the quantity of the inductance that can be generated. Now a days, there are several options to this and the silver coated Bi2223 (Bismuth strontium Calcium Copper Oxide) HTS tape has been chosen for this study. These tapes are responsive to both the perpendicular and parallel magnetic field. The critical current that flows through the tape is also dependent on temperature. Lower the temperature, higher the critical current at a specific magnetic field density [9] [16]. The critical current also differs for perpendicular and parallel magnetic field.

For this study we have only considered the perpendicular component of the magnetic field. Figure 4 is showing the relationship of the current with the magnetic flux density at some certain temperature. From these we can find out the critical current in the HTS tape. These figures are taken from the experimental results [8] determined by Kozak J. et.al. (2009).

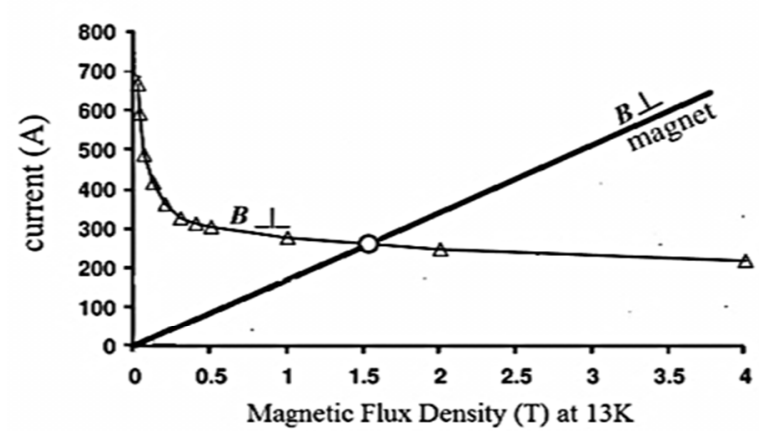

(i)

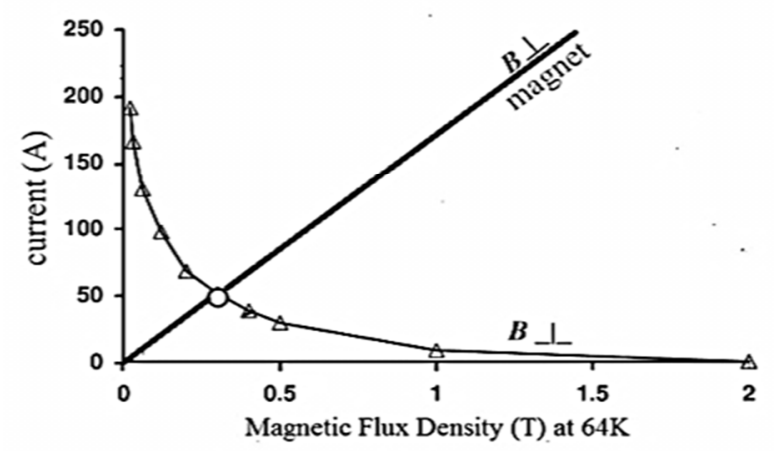

(iii)

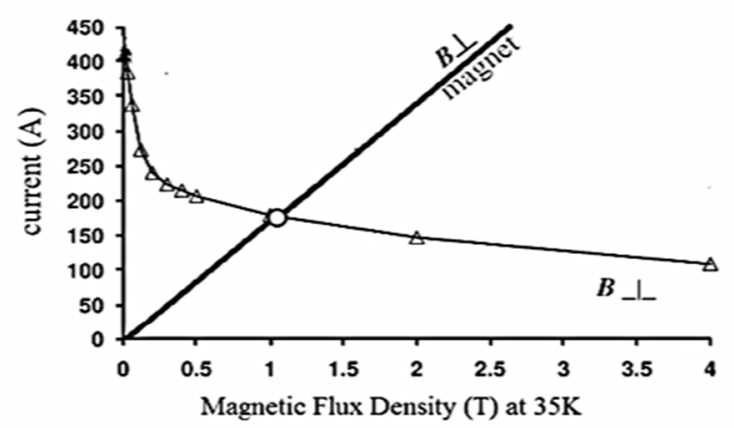

(ii)

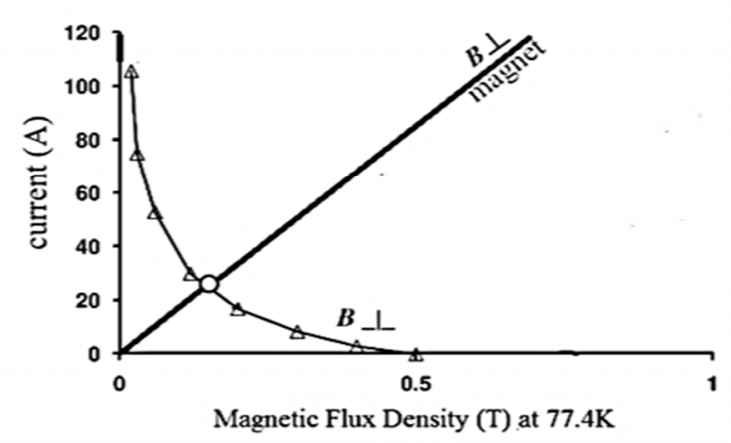

(iv)

Fig. 4. (i-iv) - $\mathrm{I}_{\mathrm{c}}$-B relationship of Bi2223/Ag HTS tape with the perpendicular field component at different low temperatures [8,9]

From the characterization we have the critical values of current for the different perpendicular magnetic field at some specific temperatures (shown in Table 1). 
Table 1.

Value of the critical currents at different temperatures for different perpendicular magnetic field component [8]

\begin{tabular}{|c|c|c|}
\hline Temperature & Magnetic flux density & Critical Current IC \\
\hline $\mathbf{7 7 K}$ & $0.15 \mathrm{~T}$ & $25 \mathrm{~A}$ \\
\hline $\mathbf{6 4 K}$ & $0.30 \mathrm{~T}$ & $50 \mathrm{~A}$ \\
\hline $\mathbf{3 5 K}$ & $1.0 \mathrm{~T}$ & $180 \mathrm{~A}$ \\
\hline $\mathbf{1 3 K}$ & $1.5 \mathrm{~T}$ & $264 \mathrm{~A}$ \\
\hline
\end{tabular}

STUDY METHODOLOGY

From section II we can see that the inductance is dependent on the several parameters like the inner diameter, outer diameter etc. for solenoid arrangement and in the toroid arrangement the toroid diameter and inner diameter of the pancake. So, several cases will be considered in this study. After the study of the inductance and energy the volume energy relationship will be presented. A comparison between these two configurations will also be presented. All the primary numerical calculations have been done with the help of SMES-PCC (superconducting magnetic energy storageparameter calculation \& characteristics) computer program developed by us. It is useful in calculating the inductance, energy and some other parameters required for designing a SMES coil [18]. Also MATLAB has been employed for additional calculations. The block diagram (Fig. 5) is showing the considerations and steps in this study.

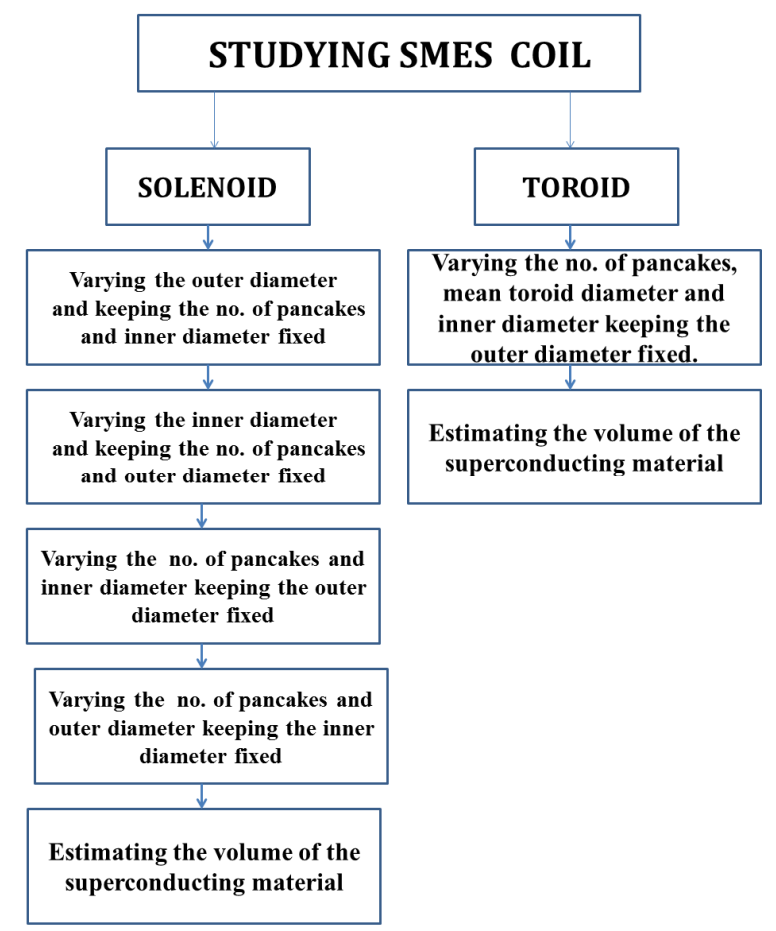

Fig. 5. Block diagram for describing the several steps and considerations in the study.

RESULTS

The tape specification is given in Table 2. As mentioned in the methodology, we have started with a fixed no. of pancake layers and inner diameter and considered some possible cases. Fig. 6 is illustrating the coil specification and the design. All the necessary illustrations have been drawn with Edraw-Max software.

Table 2.

Superconducting tape specification $[5,8,9]$

\begin{tabular}{|l|l|}
\hline \multicolumn{1}{|c|}{ Tape specification } & \multicolumn{1}{c|}{ Bi2223/Ag HTS tape } \\
\hline Width of the tape $\left(\mathrm{W}_{\mathrm{p}}\right)$ & $4.2 \mathrm{~mm}$ or 0.0042 meter \\
\hline Thickness of the tape $(\mathrm{t})$ & $0.31 \mathrm{~mm}$ or 0.00031 meter \\
\hline Critical current $\mathrm{I}_{\mathrm{c}}$ at $77 \mathrm{~K}, 0.15 \mathrm{~T}$ & $25 \mathrm{~A}$ \\
\hline Critical current $\mathrm{I}_{\mathrm{c}}$ at $64 \mathrm{~K}, 0.30 \mathrm{~T}$ & $50 \mathrm{~A}$ \\
\hline Critical current $\mathrm{I}_{\mathrm{c}}$ at $35 \mathrm{~K}, 1.0 \mathrm{~T}$ & $180 \mathrm{~A}$ \\
\hline Critical current $\mathrm{I}_{\mathrm{c}}$ at $13 \mathrm{~K}, 1.50 \mathrm{~T}$ & $264 \mathrm{~A}$ \\
\hline
\end{tabular}




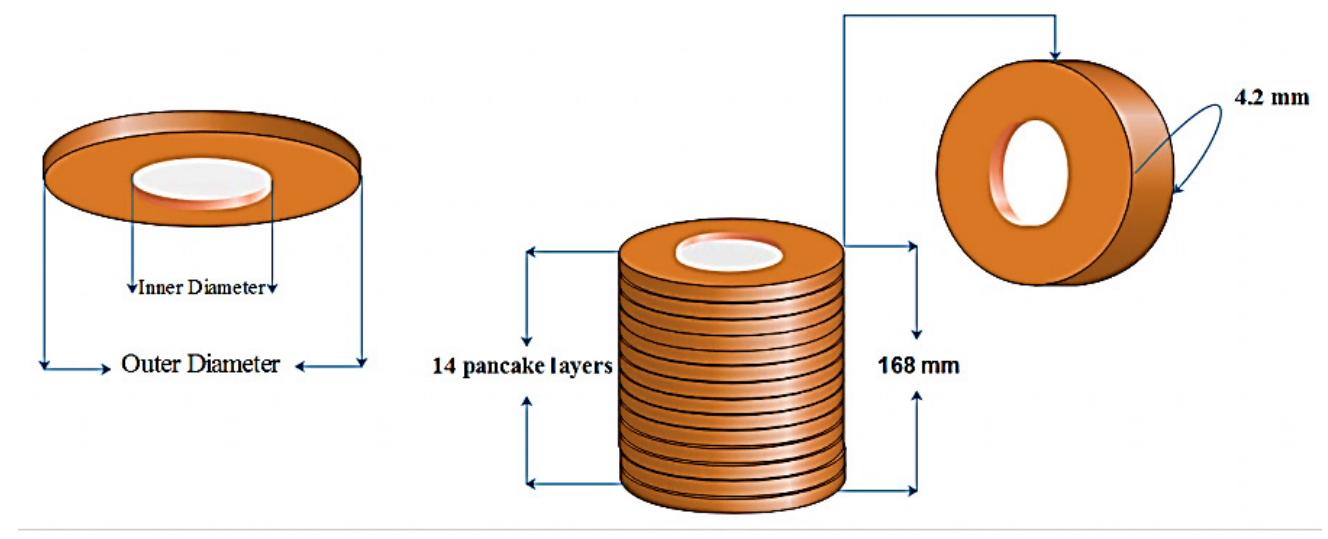

Fig. 6. Illustration of Pancake layers and solenoid arrangement (for 14 pancakes)

Fig. 7. is illustrating different values of outer diameter while keeping the inner diameter fixed. Fig. 8 is illustrating the considerations for the different values of inner diameter while keeping the outer diameter fixed. In Fig. 9, it is observed that the inductance increases when the inner diameter is retained constant and varying the outer diameter, greater the outer diameter greater the inductance and hence the energy, shown in Fig. 10. The opposite results are obtained when the outer diameter was kept constant and gradually increasing the inner diameter (Fig. 11).

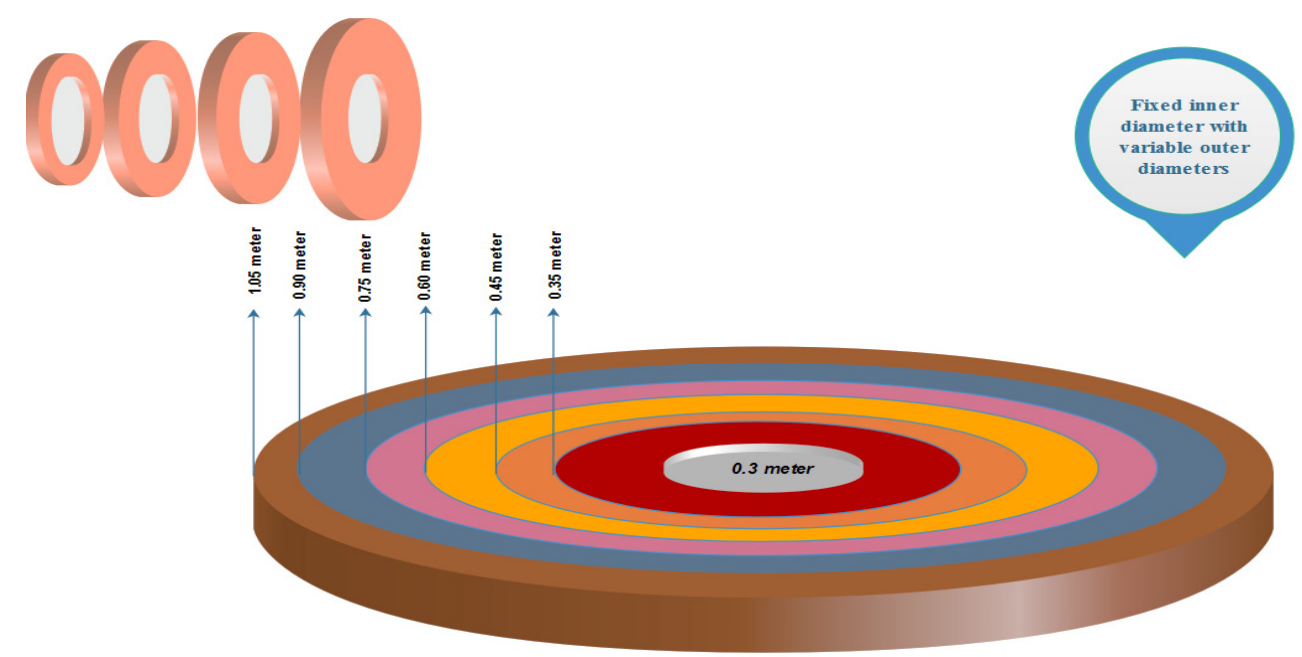

Fig. 7. Constant inner diameter with variable outer diameter
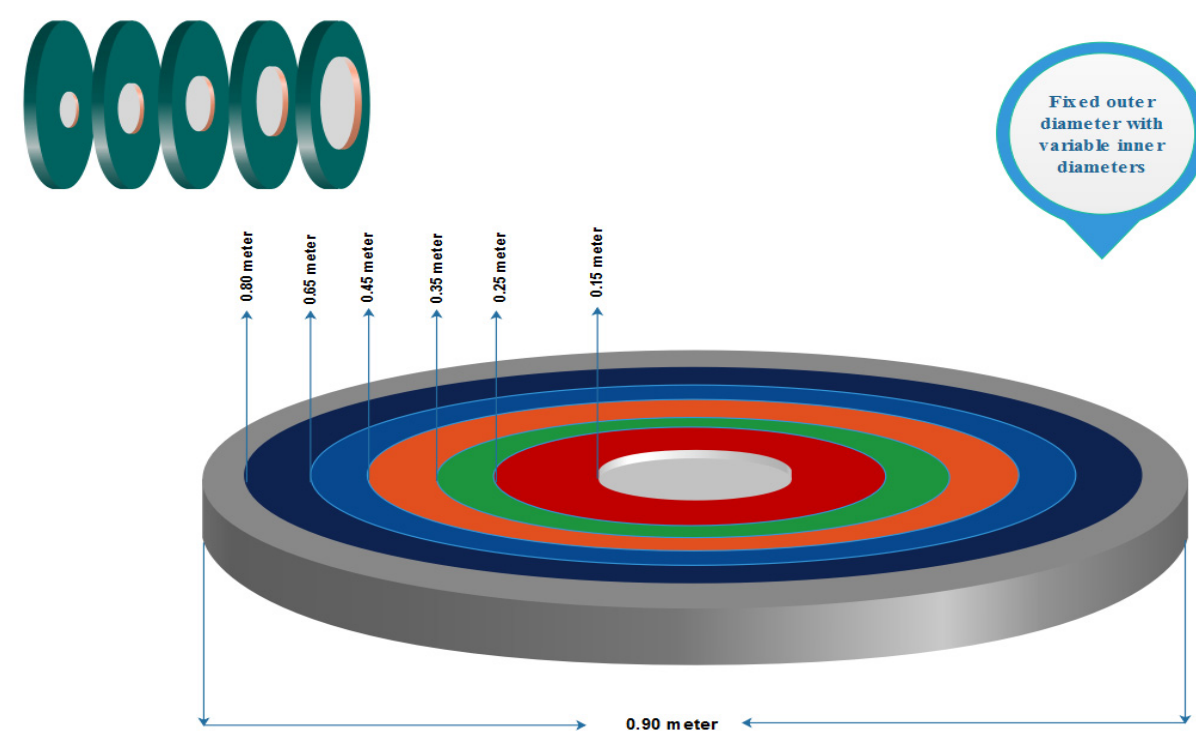

Fig. 8. Constant outer diameter with variable inner diameter 


\section{Study on Conceptual Designs of Superconducting Coilfor Energy Storage in SMES}

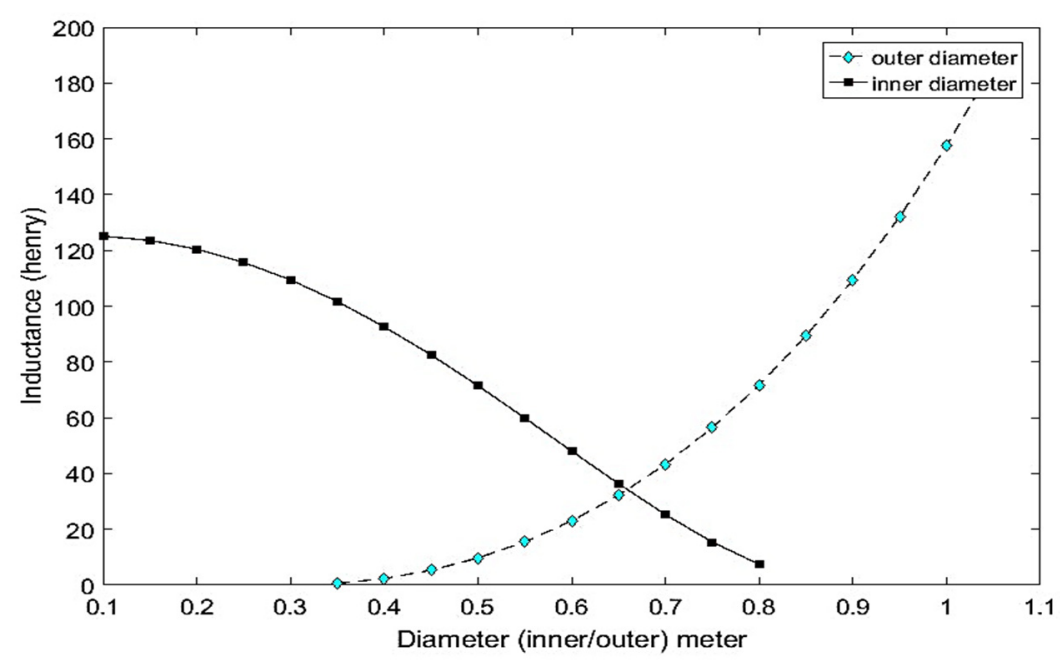

Fig. 9. Variation of inductance with inner diameter and outer diameter

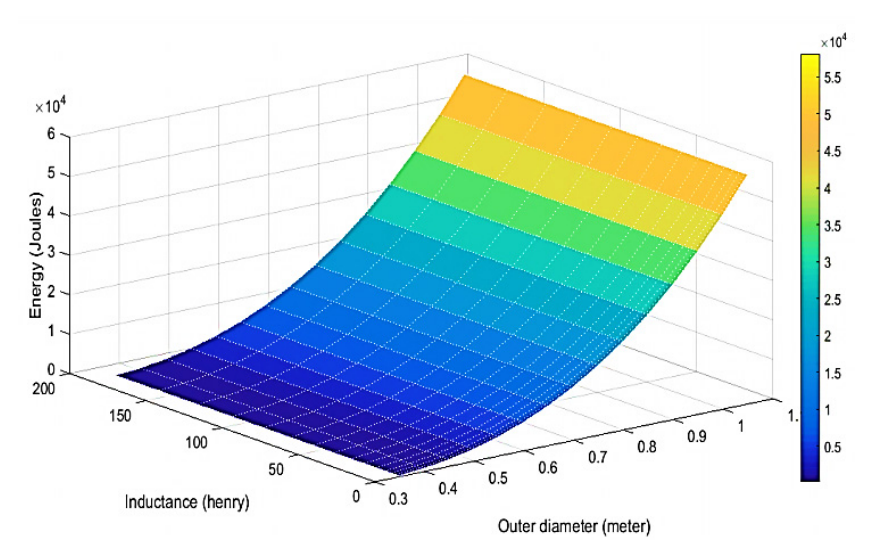

Fig. 10. Variation of inductance and energy with inner diameter at 25A@77K, 0.15T (keeping the outer diameter fixed)

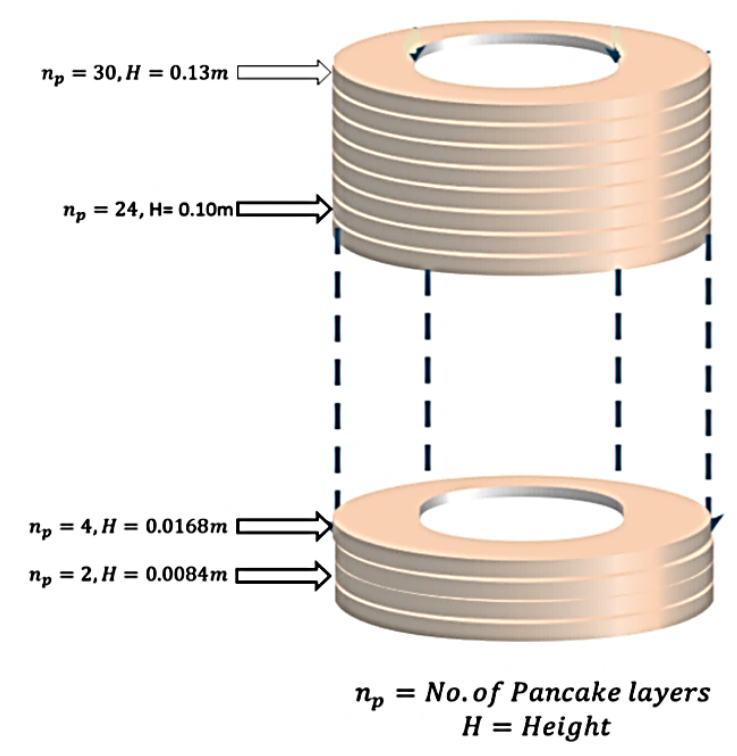

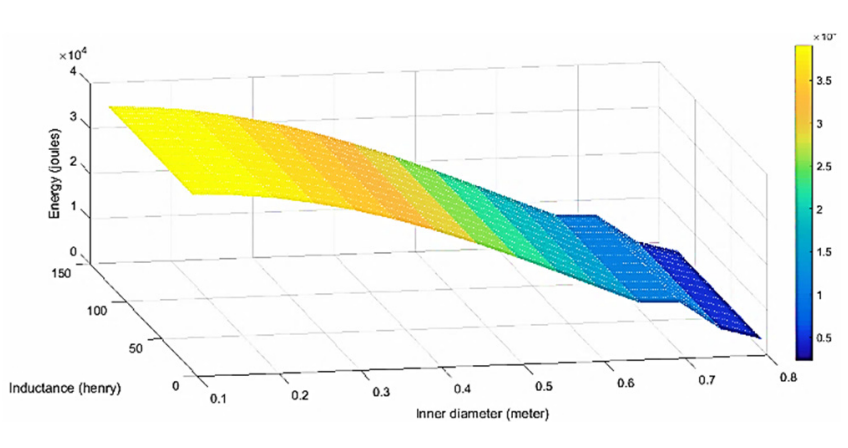

Fig. 11. Variation of inductance and energy with outer diameter at 25A@77K, 0.15T (keeping the inner diameter fixed)

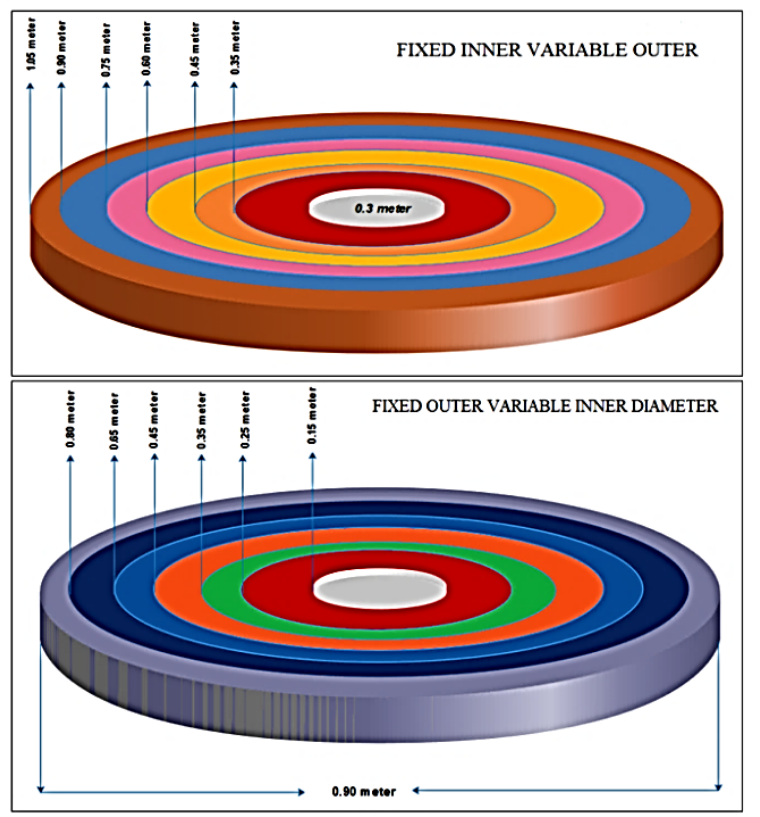

Fig. 12. Variable Pancakes consideration

Now we will observe the variation when the no. of pancakes varies with outer and inner diameters. Fig. 12 is showing the variation of pancakes with outer diameter (keeping inner diameter fixed) and inner diameter (keeping outer diameter fixed).

The calculated results (Fig. 13,14) indicate that the inductance as well as energy increases when the inner diameter is kept constant and vary the outer diameter and pancakes and vice versa. Quite interesting results obtained when we 
kept the outer diameter constant and gradually increase the inner diameter and number of pancake layers. In this case the inductance rises up for a certain configuration but ultimately the inductance starts to decrease after reaching a maximum value (Fig. 15).

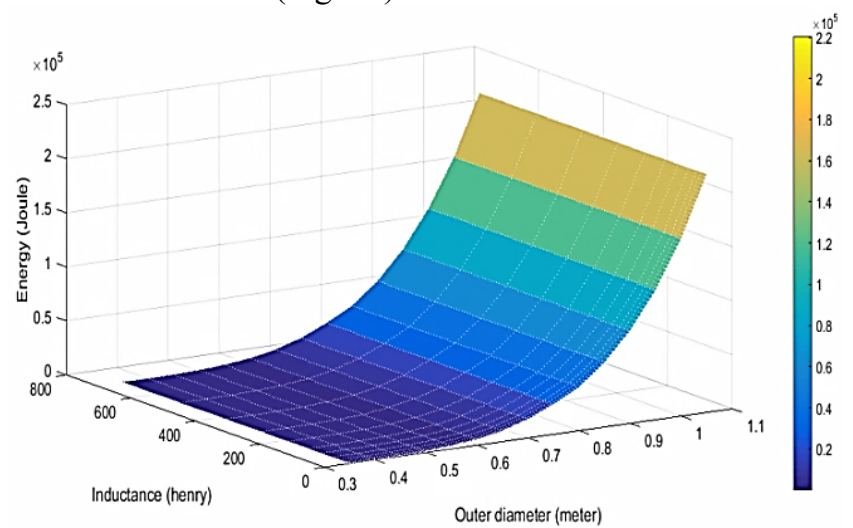

Fig. 14. Variation of inductance and energy with outer diameter at 25A@77K, 0.15T (Varying pancake layers and keeping the inner diameter fixed)

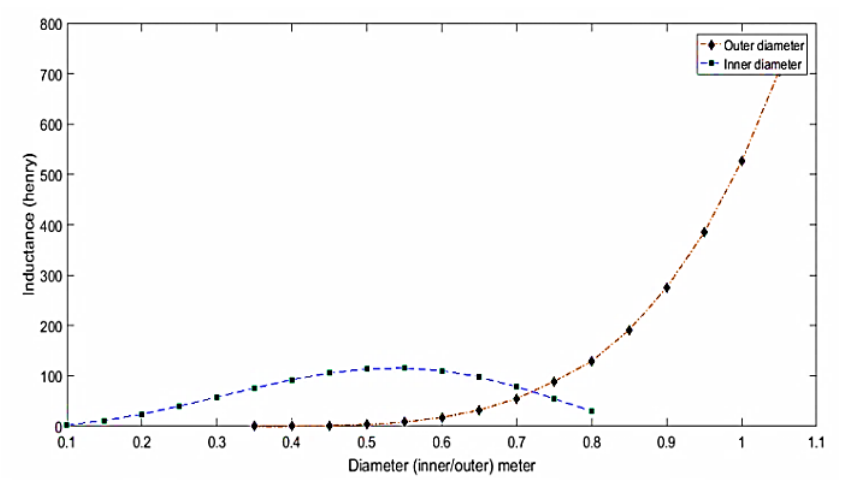

Fig. 13. Variation of inductance with inner diameter (While outer diameter is fixed) and outer diameter (while inner diameter is fixed)

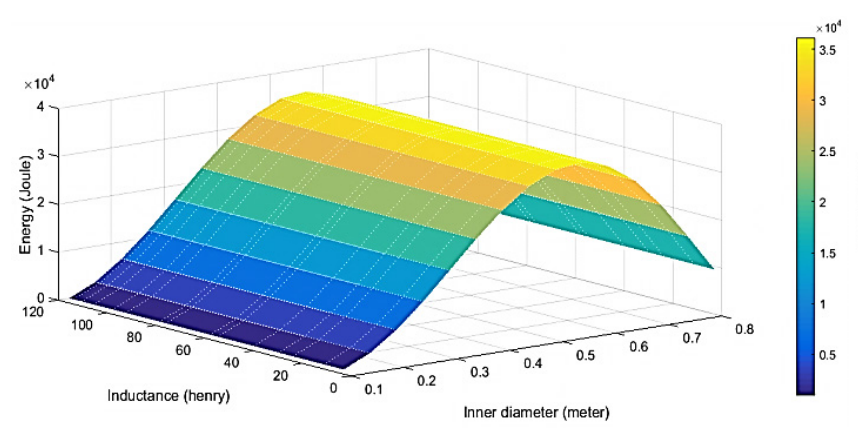

Fig. 15. Variation of inductance and energy with inner diameter at 25A@77K, 0.15T (Varying the no. of pancakes and keeping the outer diameter fixed)

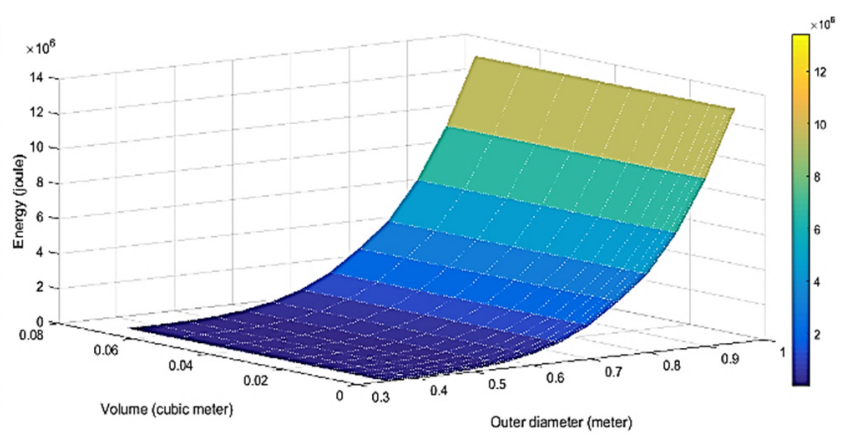

Fig. 16. Variation of Energy with volume and outer diameter at 264A@13K, 1.5T

Now considering the volume of the superconducting materials and the corresponding energy stored. The maximum energy can be obtained when we keep the inner diameter constant and vary the outer diameter at 264A @ $13 \mathrm{~K}, 1.5 \mathrm{~T}$. Considering the variation of pancakes with the constant inner diameter and varying outer diameter, the volume of the superconducting material has been calculated. We see that the energy is positively related with the volume (Fig. 16) i.e. greater the volume greater the energy output.
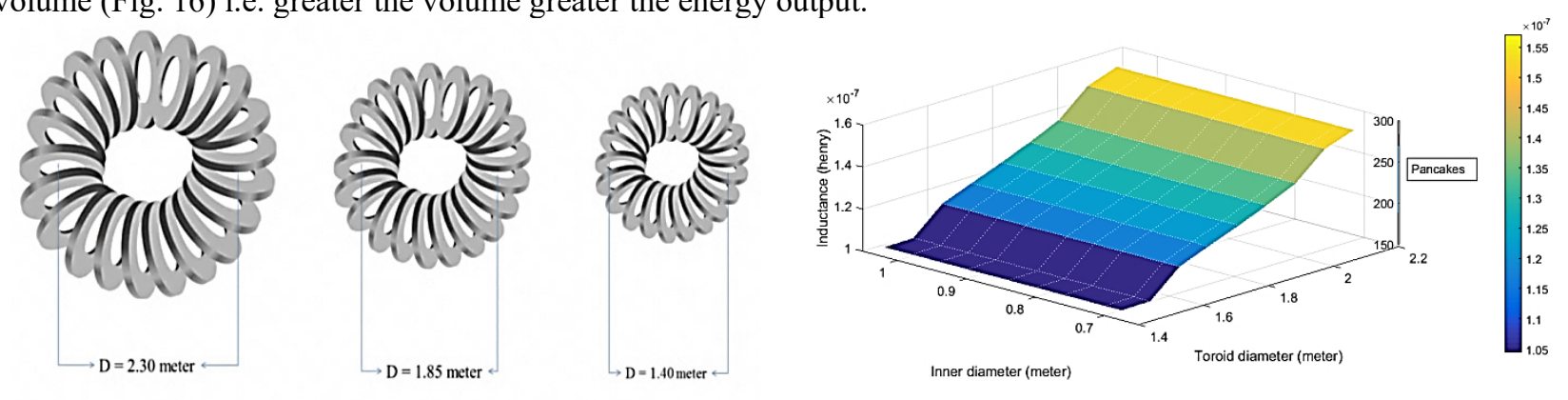

Fig. 17. Toroid design considerations

Fig. 18. Relationship between inductance, mean toroid diameter, inner diameter of the pancakes

Now we can study the toroid arrangement of SMES magnet. Fig. 17 is illustrating a few of the considerations. There are mainly two variables that determine the toroid inductance. The first one is the toroid diameter and the next one is the inner diameter of the toroid windings. So keeping the outer diameter fixed, varying the toroid diameter, inner diameter and pancakes we have calculated the values of inductance, shown in Fig. 18. 


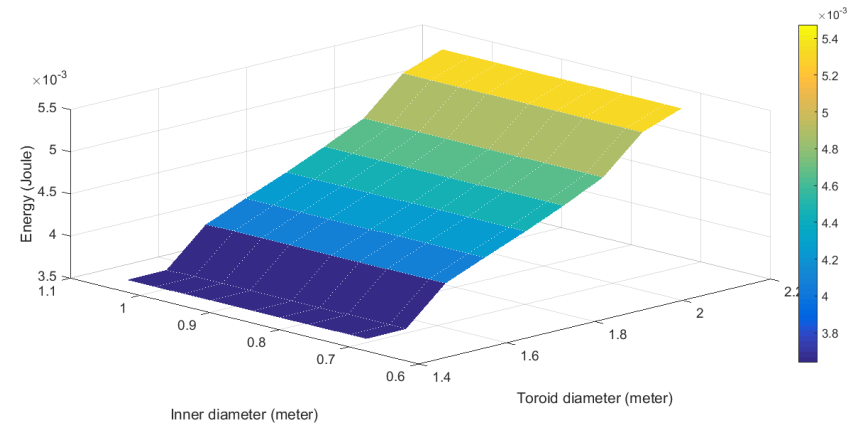

Fig. 19. variation of energy with mean toroid diameter and inner diameter(264 A@13K, 1.5T)

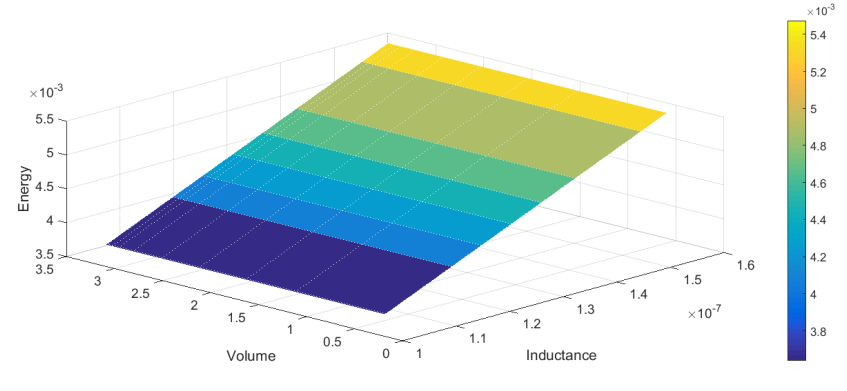

Fig. 20. Relationship among inductance, energy and volume. (At 264A, 13K@1.5T,)

From Fig. 18,19,20 it is clear that the inductance as well as energy in the toroid arrangement increases with the increase of mean toroid diameter as well as the inner diameter.

\section{DISCUSSION AND CONCLUSION}

The theoretical considerations of superconducting magnet have been demonstrated in Fig. $(6,7,8,12$ and 17) and the results are in Fig. 9-11, 13-16, 18-21, provide the understanding of the relationships among the parameters that determines the amount of the energy stored in the system. In the study of the solenoid coils or magnets, it is observed that the outer diameter should be as great as possible to ensure the maximum amount of energy stored considering the smallest possible inner diameter. This can also be understood in terms of size ratio i.e. the ratio between the inner and outer diameter, greater the size ratio greater the inductance. Also the increasing number of pancake raises the amount of stored energy. But when we want to employ less amount of superconducting material and ensure maximum energy we have to optimize the configuration with inner diameter (Fig. 15). In the case of toroid the mean toroid diameter as well as inner diameter of the pancakes plays the most substantial role in determining the quantity of energy stored in the system. The obtained results are completely in coherence with the former theoretical and experimental studies $[5,7,8$, $9,10,16]$. Though we have neglected the inter-distance between the pancakes in solenoid arrangement but it did not left any major impact on our results. This inter-distance between the pancake layers which is very tiny but definitely contribute to the height of the coil. If not omitted, the results should be the same, determined by others [8,9].

We have calculated inductance for the toroid arrangement using thin torus winding (low thickness, g). The overall results suggest that the designs we have illustrated (regarding pancake layer, critical current, etc.) are not efficient for this arrangement (toroid), even the material volume does not affect much in stored energy compared to the solenoid arrangement.

It is essential to mention that for our theoretical study we have considered the same critical current for all the configurations while calculating the energy. Practically when the dimensions or the structural parameters changes there should be changes in the magnetic field as well as the critical current. So the practical implementations for some of these configurations will definitely deviate from the theoretical results.

However, for this study BSCCO tape superconductor has been considered but there are some other alternatives like YBCO tapes $[13,14]$ or the comparatively contemporary $\mathrm{MgB}_{2}$ based superconductors [15] which are capable of attaining greater current densities ensuring greater amount of energy under the same condition as described in the HTS tape characterization. Also studies can be extended for other conceptual designs with LTS superconductors, like $\mathrm{Nb}$-Ti which has greater current density.

\section{ORCID IDs}

(D)Md. Abdullah Al Zaman https://orcid.org/0000-0002-3696-2127, DM.R. Islam https://orcid.org/0000-0002-0151-2505

(D)H.M.A.R. Maruf https://orcid.org/0000-0002-6031-3573

\section{REFERENCES}

[1] X. Luo, J. Wang, M. Dooner and J. Clarke, Applied energy, 137, 511-536 https://doi.org/10.1016/j.apenergy.2014.09.081.

[2] W. Yuan and M. Zhang, in: Handbook of Clean Energy Systems, edited by J. Yan (John Wiley \& Sons, Ltd., 2015). https://doi.org/10.1002/9781118991978.hces210.

[3] M.A. Al Zaman, S. Ahmed and N.J. Monira, in International Conference on Nanotechnology and Condensed Matter Physics (Dhaka, Bangladesh, 2018), https://doi.org/10.13140/RG.2.2.20403.53289/1.

[4] W. Hassenzahl, IEEE Transactions on Magnetics, 25(2), 799-1802 (1989), https://doi.org/10.1109/20.92651.

[5] C. Chao and C. Grantham, in: AUPEC 2005 Australasian Universities Power Engineering Conference, edited by M. Negnevitsky (School of Engineering, University of Tasmania, 2005), pp. 375-379.

[6] M.R. Islam, Study of SMES technology for electric power supply and investigation of its utility and possible implementation in Bangladesh: A Project report, (University of Chittagong, July 2014).

[7] F. Ştefănescu, Annals of the University of Craiova, Electrical Engineering series, 35, 2011, http://elth.ucv.ro/fisiere/anale/2011/33.pdf.

[8] J. Kozak, M. Majka, L. Jaroszynski, T. Janowski, S. Kozak, B. Kondratowicz-Kucewicz and G. Wojtasiewicz, Journal of Physics: Conference Series, 234(3), 032034 (2010), https://doi.org/10.1088/1742-6596/234/3/032034. 
[9] G. Wojtasiewicz, T. Janowski, S. Kozak, B. Kondratowicz-Kucewicz and M. Majka, Journal of Physics: Conference Series, 97(1), 012019 (2008), https://doi.org/10.1088/1742-6596/97/1/012019.

[10] J. Kozak, S. Kozak, T. Janowski and M. Majka, IEEE Transactions on Applied Superconductivity, 19(3), 1981-1984 (2009), https://doi.org/10.1109/TASC.2009.2018753.

[11] A. Morandi, M. Fabbri, B. Gholizad, F. Grilli, F. Sirois and V.M. Zermeño, IEEE Transactions on Applied Superconductivity, 26(4), 1-6 (2016), https://doi.org/10.1109/TASC.2016.2535271.

[12] S.S. Kalsi, D. Aized, B. Conner, G. Snitchier, J. Campbell, R.E. Schwall, J. Kellers, T. Stephanblome, A. Tromm and P. Winn, IEEE transactions on applied superconductivity, 7(2), 971-976 (1997), https://doi.org/10.1109/77.614667.

[13] Zhu, J., Yuan, W., Coombs, T.A. and Ming, Q., 2011. Simulation and experiment of a YBCO SMES prototype in voltage sag compensation. Physica C: Superconductivity, 471(5-6), 199-204 (2011), https://doi.org/10.1016/j.physc.2010.12.015.

[14] K. Higashikawa, T. Nakamura, K. Shikimachi, N. Hirano, S. Nagaya, T. Kiss and M. Inoue, IEEE Transactions on Applied Superconductivity, 17(2), 1990-1993 (2007), https://doi.org/10.1109/TASC.2007.898947.

[15] R. Hott, R. Kleiner, T. Wolf and G. Zwicknagl, (2013), e-print https://arxiv.org/abs/1306.0429.

[16] B. Kondratowicz-Kucewicz, T. Janowski, S. Kozak, J. Kozak, G. Wojtasiewicz and M. Majka, Journal of Physics: Conference Series, 234(3), 032025 (2010), https://doi.org/10.1088/1742-6596/234/3/032025.

[17] S. Nomura, H. Tsutsui, S. Tsuji-Iio, H. Chikaraishi and R. Shimada, in Proceedings of the Fifteenth International Toki Conference on "Fusion and Advanced Technology", 81(20-22) 2535-2539 (2006), https://pascalfrancis.inist.fr/vibad/index.php?action=getRecordDetail\&idt=18346799.

[18] Md. Abdullah Zaman, https://doi.org/10.13140/RG.2.2.32352.53760.

\section{ДОСЛІДЖЕННЯ КОНЦЕПТУ КОНСТРУКЦІЇ НАДПРОВІДНОЇ КОТУШКИ ДЛЯ ЗБЕРІГАННЯ ЕНЕРГІЇ В ННМЕ}

М. Абдулла Аль Заман

${ }^{a}$ Кафедра текстильної техніки, Північний університет Бангладеш, Дака, Бангладеш

${ }^{b}$ Кафедра фізики, Університет Чіттагонг, Чіттагонг 4331, Бангладеш

${ }^{c}$ Фізичний факультет, Чіттагонгський інженерно-технологічний університет, Чіттагонг, 4349, Бангладеш

Надпровідний накопичувач магнітної енергії (HHME) - надзвичайно перспективний пристрій для зберігання енергії через ефективність його циклу та швидкий відгук. Хоча повсюдне використання пристрою ННМЕ обмежене через величезну вартість кріогенної системи охолодження для підтримки надпровідного стану, але з постійною еволюцією надпровідників 3 високим Тс, НHМЕ перетворюється на головного конкурента існуючих пристроїв акумулювання енергії в майбутньому. Серед декількох його частин надпровідна котушка $\epsilon$ найважливішим сегментом цієї технології, а індуктивність, що створюється в котушці, визначає кількість накопиченої енергії. У цій роботі продемонстровані можливі геометричні конфігурації котушки НHМЕ. Надпровідні стрічки з високим Тс зазвичай використовуються у всьому світі для формування цих конфігурацій. У роботі розглянута надпровідна стрічка з ВСКМО (вісмут-стронцій-кальцій-мідний оксид)-2223 для вивчення концептуальних конструкцій надпровідної котушки ННMЕ. Спочатку були визначені значення критичного струму при різній щільності магнітного поля та температурі шляхом вивчення характеристик надпровідних стрічок. Представлені чисельні результати та співвідношення між декількома параметрами як для соленоїдної, так і для тороїдної конфігурацій у різних специфікаціях. Виходячи з результатів, встановлено, що співвідношення розмірів у соленоїді та середній діаметр тороїда в розташуванні тороїдів відіграє важливу роль у генерації індуктивності, а отже, і в накопиченні енергії. Результати також відповідають дослідженням інших авторів. Надано пропозиції щодо максимального підсилення енергії для конкретної соленоїдної конфігурації. Також були коротко представлені майбутні сфери досліджень 3 альтернативними надпровідними стрічками та їх обмеження.

КЛЮЧОВІ СЛОВА: ННМЕ, індуктивність, накопичувач енергії, соленоїд, тороїд.

\section{ИССЛЕДОВАНИЕ КОНЦЕПТА КОНСТРУКЦИИ СВЕРХПРОВОДЯЩЕЙ КАТУШКИ ДЛЯ ХРАНЕНИЯ ЭНЕРГИИ В СНМЭ}

М. Абдулла Аль Заман ${ }^{\mathrm{a}}$, Н.Г. Ислам'

${ }^{a}$ Кафедра текстильной техники, Северный университет Бангладеш, Дакка, Бангладеш

${ }^{b}$ Кафедра физики, Университет Читтагонг, Читтагонг 4331, Бангладеш

${ }^{c}$ Физический факультет, Читтагонгский инженерно-технологический университет, Читтагонг, 4349, Бангладеш Сверхпроводящий накопитель магнитной энергии (СНМЭ) - чрезвычайно перспективное устройство для хранения энергии из-за эффективности его цикла и быстрый отклик. Хотя повсеместное использование устройства СНМЭ ограничено из-за огромной стоимости криогенной системы охлаждения для поддержания сверхпроводящего состояния, но с постоянной эволюцией сверхпроводников с высоким Тс, СНМЭ превращается в главного конкурента существующих устройств аккумулирования энергии в будущем. Среди нескольких его частей сверхпроводящая катушка является важнейшим сегментом этой технологии, а индуктивность, создаваемая в катушке, определяет количество накопленной энергии. В этой работе продемонстрированы возможные геометрические конфигурации катушки СНМЭ. Сверхпроводящие ленты с высоким Тс обычно используются во всем мире для формирования этих конфигураций. В работе рассмотрена сверхпроводящая лента с ВСКМО (висмут-стронций-кальций-медный оксид)-2223 для изучения концептуальных конструкций сверхпроводящей катушки СНМЭ. Сначала были определены значения критического тока для различной плотности магнитного поля и температуры путем изучения характеристик сверхпроводящих лент. Представленные численные результаты и соотношение между несколькими параметрами как для соленоидных, так и для тороидальных конфигураций в различных спецификациях. Исходя из результатов, установлено, что соотношение размеров в соленоиде и средний диаметр тороида в расположении тороидов играет важную роль в генерации индуктивности, а следовательно, и в накоплении энергии. Результаты также соответствуют исследованиям проведенными другими авторами. Даны предложения по максимальному усиления энергии для конкретной соленоидный конфигурации. Также были кратко представлены будущие сферы исследований с альтернативными сверхпроводящими лентами и их ограничения.

КЛЮЧЕВЫЕ СЛОВА: СНМЭ, индуктивность, накопитель энергии, соленоид, тороид. 